\title{
Arbitration as an Alternative to Litigation in Construction Projects
}

\author{
Henry C. Ajaelu, Reuben A. Okereke
}

\begin{abstract}
In many countries of the world, arbitration has been used as an alternate disagreement resolution technique, which remains a form of dispute settlement process outside a courtroom. Disagreements and conflicts in the construction industry have been viewed as disagreeable events in the implementation of projects by numerous researchers and these harm costs, performance, and complete objectives. Such conflicts have in the past been settled by litigation and lawsuits in which commercial ties were ultimately destroyed. The study employed four research objectives and research questions. Data used for the study existed from secondary and primary sources. Secondary records were assembled from related works on preceding studies although primary data were collected from fact-finding. The sample size is 100 respondents made up of staff from the Federal Ministry of Works and the state ministry of works in Owerri, Imo State, Nigeria. Four establishments of higher learning in Imo State were also covered. A list of contractors was assimilated from the federation of building and civil engineering contractors Imo State branch. The study exposed that arbitration has been established to be worthwhile and less time overwhelming. Furthermore, usage of arbitration is additional facilitated by the inclusion of an arbitration clause in most construction contracts which usually states that all disputes arising in the contract shall be settled by arbitration. The study concludes that the use of arbitration in dispute resolution in construction contracts not only minimizes cost and time but also facilitates cordial relationships among the parties after the dispute and this minimizes the incidence of project failure and abandonment in the construction industry. It recommended that in addition to proper education on the use of arbitration, there should be adequate enlightenment and awareness creation on the importance and use of arbitration in the building industry, especially in the informal sector.
\end{abstract}

Keywords: Arbitration, Litigation, Construction Projects

\section{INTRODUCTION}

F or a faultless world of construction, there shouldn't be conflicts, and for sure, there is no ideal construction industry. Most scholars have considered construction conflicts to be unavoidable because, given all the studies carried out on construction disputes, there are still significant disputes within the sector (Acharya \& Lee, 2006). Recent studies agree with old studies that disputes on construction projects

Revised Manuscript Received on April 26, 2020.

* Correspondence Author

Ajaelu Henry*, Department of Urban and Regional Planning, Enugu State University of Science And Technology, Enugu, Nigeria, Email: Ajaelu.henry@esut.edu.ng

Reuben Okereke, Department of Quantity Surveying, Imo State University, Owerri, Imo State, Nigeria.

(c) The Authors. Published by Blue Eyes Intelligence Engineering and Sciences Publication (BEIESP). This is an open access article under the CC BY-NC-ND license (http://creativecommons.org/licenses/by-nc-nd/4.0/) are inevitable. Conflicts in construction projects are, therefore, considered inherent, whilst disputes in such projects are all-around and difficult to avoid (Zack, 1995). However, the prevention of construction disputes was found to be challenging, if not impossible (Kassab, Hipel \& Hegazy, 2006). Disputes in the construction sector were identified by Cheung (1999) as an endemic problem. Many of them, therefore, regard a construction project as a matter of dispute (Patterson \& Seabolt, 2001 cited in (Zuhairah, Azlinor \& Rozina, 2010). Construction, as distinguished by Dubois and Gadde, (2002), is becoming particularly complex due to specific complexities and interdependencies in the sector. This is because construction contracts are typically executive and often include anticipatory vocabulary for future events. Accordingly, the parties to such arrangements shall in effect execute their part of the contract. Not all eventualities should, indeed, be drawn up, because in the building phase conflicts have therefore become inevitable (Cheung, 1999). This displays that disagreements have become recognized in construction developments, such as a result of the multifaceted appearance of these projects and the reliance of people, more to include a large number of participants in the construction project. Therefore, there are so many variables that can result in inconsistencies as a consequence of the future events surrounding construction. In the construction sector, the words disagreement, conflict, and quarrel are often interwoven, but their meaning differs greatly (Al-Tabtabai \&Thomas, 2004). Conflicts in construction projects would arise, according to Fenn, O'Shea, and Davies (1998), where inconsistent contractual interests exist. A dispute can emerge from unresolved disputes, according to (Tazelaar \& Snijders, 2010). Furthermore, the dispute was described as serious disagreement and consensus on a big issue. Otoo (2010) argues that the disagreement is not factual and that it's an independent issue, a common-sense approach based on facts, laws, and policy factors, and that there is no clear interpretation in the matter. Construction differences have also been well-defined as' all types of disagreement arising from construction projects, in specific those relating to service execution (such as mechanical and engineering services) and construction projects' (Ndekugri and Russell, 2006). Therefore, Love, Davis, London, and Jasper (2008) establish that a lawsuit does not occur until a petition has been made and denied, as concerning a conflict under the Halki concept (Halki Shiping Company v Sopex Oils Ltd), a claim is an application for compensatory payments for damages incurred by any party to a deal.

Published By:

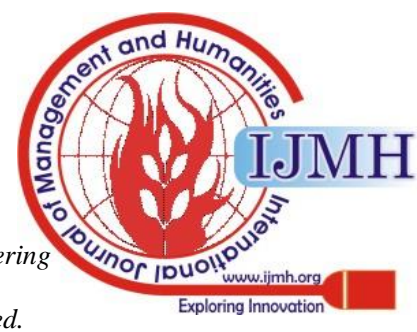


Consequently, any argument not accepted by the parties would lead to a disagreement, which would lead to litigation if not settled by the parties. Disputes may occur as a consequence of unresolved conflict in construction projects; whereas conflict itself is contested by a disputable claim between the contracting parties. In other terms, an argument which the parties involved in the building agreement do not generally consent upon is followed by a construction disagreement.

The situation is an unsuccessful fact that many building developments end in differences, driving the parties into some form of disagreement tenacity. Several of these construction differences are resolved through negotiation, which is a procedure by which the parties in disagreement, in its place of going to court for a resolution to the matter, agree to yield their case to a neutral third-party, recognized as the arbitrator, who acts as a reviewer and jury (Harmon, 2013). Arbitration is often confused with mediation and, sometimes, with a lawsuit. Each contains different forms of dispute resolution. Mediation is a settlement meeting in which the parties see (typically in person) and use a neutral third-party to act as a settlement architect. The neutral third-party is called the intermediary. Though the intermediary has the authority to conduct and direct the mediation, the mediator has no authority to force or induce settlement. The parties yield to their dispute to the intermediary either because a court or a contract provision requires that they do so, or because they feel the intermediary will be able to simplify a settlement that might not otherwise be achieved without a mediator's assistance (Love, Davis, Ellis \& Cheung, 2010). Nevertheless, eventually, the parties can refuse to settle. This brings to fore the need for arbitration as a substitute to dispute resolution in construction projects in Nigeria.

\section{A. Statement of the Problem}

Construction projects are getting very complicated every day. Also, individuals with a large range of education and skills need to be interested in. Some disputes and disagreements are inevitable with so many participants employed in numerous trades and professions (Harmon, 2013). Building/infrastructure is one of the world's fastest-growing markets and much money is spent on litigation related to development. Speedy globalization and the subsequent rise in market rivalry have also led to increased trade disputes in Nigeria (Oluwasiyaki, 2011). In several situations, moreover, the growth rate of the dispute settlement systems has been superior to the pace of industrial growth, transformation, and changes in socio-economic circumstances. For centuries, arbitration was used by traders to resolve disputes. Private arbitration is now widely recognized and acknowledged as a mechanism for dispute resolution. Arbitration is an alternative method to the normal judicial method of settling disputes activated through a court of law proceeding. Of various forms, including conciliation, mediation, and negotiations, of alternative dispute resolution (ADR), Arbitration has evolved as one of the most widely accepted and influential forms of ADR. The construction industry was a major factor in Nigerian growth, but very little or no money for conflict management and dispute settlement is available to the parties involved; conflict management problems are a big challenge and dispute settlement issues are very time-consuming and costly. The main challenge of this work is to ascertain the necessity of arbitration as an alternative dispute resolution in construction projects in Nigeria

\section{B. Purpose of the Study}

The specific objectives are:

1. To determine the elements that affect the practice of arbitration on civic construction developments

2. To ascertain disputants' fulfillment with the use of arbitration as in contrast to a lawsuit in terms of cost

3. To ascertain disputants' fulfillment with arbitration as against lawsuit in terms of time spent

4. To ascertain disputants' fulfillment with arbitration as against lawsuit in terms of conservation and sustainability of relationships

\section{Research Questions}

1. What are the factors which shake the use of arbitration on community construction projects in Nigeria?

2. What is disputants' fulfillment with the use of arbitration as against lawsuit in terms of cost?

3. What is disputants' fulfillment with arbitration as against lawsuit in terms of time spent?

4. What is disputants' fulfillment with arbitration as against lawsuit in terms of maintenance and sustainability of relationships?

\section{LITERATURE REVIEW}

\section{A. Arbitration Concept}

Arbitration is a way of resolving contractual conflicts whereby the parties settle the contested issue without proceeding to the courts. The parties shall listen to their case and decide by a non-partisan third party known as an arbitrator. The trial is outside a session, but close to a jury, where testimony and facts are provided from both sides. Because arbitration has been described as a way of relieving the burden of court schedules, the decision taken by the arbitrator is always final (Tazelaar \& Snijders, 2010).

The arbitration process is supervised by a professional arbitrator who facilitates communication between the two parties to an argument. The arbitrator may be an advocate or not, and many of the former judges are arbitrators. Frequently the most successful arbitrators are knowledgeable of the issues and have a familiarity with them. For example, a specialist in the job sector or former administrative officer in the job division of the state may settle a workplace conflict easily.

\section{B. Negotiation in the Construction Industry}

Arbitration also is known as negotiation is an isolated, prescribed form of disagreement resolve for the construction industry. This calls for a third-party arbitrator or arbitration tribunal to settle conflicts, appointed by the parties to this conflict. Disputes shall be resolved in compliance with the relevant legal evidence, laws, and standards (Tazelaar \& Snijders, 2010). 
An appointed arbitrator administers the arbitration process, subject to all applicable contractual guidelines and the legislative controlling framework of the local courts. There are only limited appeal rights and the successful party

Arbitration starts with the notice of agreement specifying that an arbitrator is chosen by an approving authority (who is to be specified in the contract) if no arbitrator can be appointed by that entity. In the tiered dispute resolution procedures, arbitration is usually combined with adjudication and mediation. According to Tazelaar and Snijders (2010), in the construction industry arbitration has already been said to be a means for dispute resolution, and the parties must, therefore, agree to refer their dispute to arbitration, as a precondition for arbitration. The Arbitration Agreement is the name of such consent. Arbitration agreements can either be oral or published, as in most agreements. However, the arbitration agreement must be written to comply with the provisions of the Law. A single provision in the main treaty itself can simply be in most regular buildings because one clause within the primary treaty itself does not require a separate and different arrangement from the principal agreement between the parties. An arbitration promise most not be a distinct and different promise from the original agreement with both itself in fact in most regular systems of construction promises this is the case. Arbitration promise contains papers endorsed by the client and contractor, by exchanging letters, telegrams, or other resources of communication. This offers a track of promise or reports of prerogative in which the existence of the agreement is assumed by any of the party and not deprived of by the other. There reference in an agreement to a document covering an arbitration clause constitutes an arbitration agreement if the contract is in writing and the situation is such as to make that arbitration section part of the contract (Cheung \& Yiu, 2006).

\section{Causes of Disputes on Construction Projects}

Several scholars have established the sources of conflict regarding construction projects and in the view of Zack (1995), disagreements are not mysteriously evident during the building period. The problem seeds are normally planted during the design process but surface during building, according to the report. Love et al (2008) claim that there are many sources of conflicts in buildings and that due to the complexity involved with building projects, a specific cause cannot be established. The complexity of modern construction projects is also the and can also sometimes contribute to dynamic disagreement over the scope and scale of the job, numerous contracting partners, badly written and/or performed documents, inadequate preparation, financial issues, and coordination issues (Cheung \& Yiu, 2006). Cheung and Yiu (2012) and Love, Davis, Ellis, and Cheung (2010) agree frequently that disagreement is the display of fundamental conflicts and that it is related to differences of viewpoint, interests, and human agenda. "Dispute emerge not only from the harmful or inappropriate dispute but also from the unfriendly resolution of arguments" (Kumaraswamy, 1998; 1997) discovered that disagreements occur when an entitlement is disallowed and the rejection is not acknowledged by the other party. A comparative research review in the US of 24 conflicts over chosen buildings developed a model indicating that three components formed the basis of the problem situation of construction projects typically receives legal costs. parties, it may be of a single section inside the key contract

(Chan and Suen, 2005). The components are mission ambiguity, contractual partnerships, and successful resolution of issues. Building projects are typically innovative and are prone to uncertainty which may trigger conflicts because the project partners lack an appreciation of the final results. The degree of mistakes in the contract documents and the shift of project scope that could eventually lead to a claim and disagreement may be included in this uncertainty (Chan and Suen, 2005). It might still be accumulated by the operational relations between the members and their failure to solve problems as they come may finally lead to misinterpretations.

Also, Zaneldin's (2006) study suggests as a primary source of conflicts on construction ventures' financial, cultural, and legal problems. Similarly, amendments prepared for the agreement and additional labor imposed by the client were identified in a study conducted in the United Arab Emirates as a mutual type of rights that could lead to conflicts in construction (Blake, 2006). Six variables in Korean construction were established as triggers of disputes (Acharya \& Lee, 2006). It includes changing the website's status, public splits, assessment of order modifications, construction errors, unnecessary quantity adjustment, and dual-purpose importance. The study also found that changes in contract scope, agreement definition, and allowance of time claims as well as site situations that add to conflicts about building projects, as Blake (2006) noticed them in the report. The results also comprise late, unfinished or insufficient project information, problems with approvals, site access, and plan quality, and resource accessibility as contested factors in building projects. All of the experiments listed above were consistent in the conclusions surrounding extra activities or discrepancies requested by the client to contribute to building conflicts. This is especially to minimize the anticipated cash contribution by the contractor and consequently impact the expected profit on the job as a result of a rapid and significant change in the project. Nevertheless, the contractor would like to oppose these changes; thus, inconsistencies could occur because of such opposition that could eventually lead to conflicts. In the view of Kululanga, Koutcha, McCaffer, and Edum-Fotwe, (2011), mistakes, flaws, and omissions in contract contracts, are an underestimation of real project costs at the outset, as well as a change in terms and parties involved in the project are all causes of contention in the building. He also argued that three factors, namely project insecurities, contractual problems, and opportunistic conduct, drive the development of a dispute about construction works. Therefore, Poh (2015) divided these disputes into three main groups, recognizing disputes resulting from contractual relationships between the consumer entities. These includes:

(a) The time associated (entitlements from the worker for rescheduling of the period for accomplishment of the project),

(b) Cash linked (privileges from the worker for reimbursement of the value of differences or compensation of loss and outflow), and

\section{Published By:}

Blue Eyes Intelligence Engineering

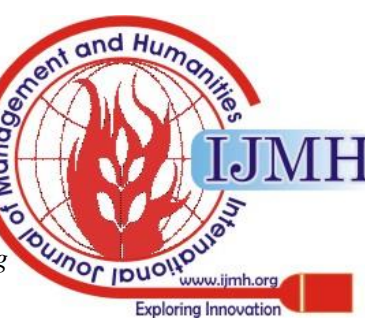




\section{Arbitration as an Alternative to Litigation in Construction Projects}

(c)

Value linked (declarations by the client of faulty materials and other related issues).

The above suggests that clients would be undesirably affected by contractor's request for the unreasonable extension of the project completion date and claims for additional services or failure and cost, particularly when such claims sound unnecessary. Contentious issues will also occur where construction work is done by way of faulty materials and manufacturing because consumers expect to have an aggregate for the money capitalized on the project's implementation. This nevertheless suggests that clients would not be willing to yield to negotiate the quality of the works, and will kick at any effort by the contractor to provide a job that does not conform to the conditions contained in the promise.

Also, a survey of public project delays in Jordan revealed the principal cause for a dispute over the design, the changes of orders, weather, and the conditions at the premises, the delivery delays, economic conditions, and the increase in work volume. However, this study coincided with previous researchers, showing that the factors responsible for disputes about the projects of public or private clients do not differ (Hansen, 2012).

However, specific conflicts relating to project in the public works have been exposed, which includes breaches of the terms of conditions of the contract, insufficient description of the job sketch, delays in the owner's forward paid payment, bad-estimation of finished works, incorrect quantitative repo rts and impractical contract terms. This study found that the problem emerged concerning the project of the public consumer where the parties do not agree with the terms of the contract and the design plans of the project have not been well documented. Worse assessment of work completed before payment for work done is also a critical dispute in that this affects the cash flow plan of the contractor.

An incorrect quantity test could contribute to the contracting company statements and functions by the quantity checker of the buyer, which could also impact the cash flow of the client in question where the amount of work in the contracts was under-measured. Unrealistic contract terms can also impact the date of completion of the project and ultimately lead to the inability of the public client to seek the contracting contractor's liquidated damages for a late termination. But that will lead to a dispute if the contractor does not accept such a deduction. The complexity and scale of the work to be done will also affect the type of conflicts that may arise during project development. In complex construction can also often lead to complex disputes, mainly arising from complex work and the scope of the project, multiple contracting parties, contract documents that have been poorly prepared and/or carried out, improper plan, financial issues and communication issues that arise during the execution of the project.

\section{Arbitration over Litigation for Construction Project Delivery}

The main objective of arbitration conferring to El-adaway \& Ezeldin (2007) is to certify that the contractual obligations are met and to compensate for all violations of these obligations. Research by Taylor and Carn (2010) suggests that construction disagreements need to be resolved as rapidly as possible to reserve the stability of the business and professional relations. Conflict avoidance is always more relevant than dispute resolution, however, in the opinion of Taylor and Carn (2010), in this way, claims and disputes can be prevented from spreading to disputes. While many people advocate dispute resolution, it is important to avoid and carry out disputes of others in the early days to save time and costs. Cheung et al (2010) suggest that the goal of preventing the deterioration of negatives on project results and proactively handling the conflict and finding early settlement is realistic. The work then can progress, and if the total and final resolution has not been reached the parties may seek further resolution.

Negotiation and lawsuit, seem to be the oldest systems of dispute determination method. Carmichael (2012) recommended that the step of methods to disputes resolution should be as follows:

1) Timely effort to solving the problem in the manner and level at which it appear.

2) Perhaps this this not work, including people with verdict making expertise at the higher level to arbitrate in the dispute.

3) If this approach fails, the parties should proceed using an independent third party.

4) If this also fails, the disputants may use negotiation and lawsuit.

Construction litigation has been described as costly, timely, full of flaws, and a weakening process, ending in a situation in which " the winner" is sometimes the" the loser', where avoidance can cost more than engaging and Arditi et al. (1998). Most scholars, for example, the Construction Industry Institute (CII) 1995 stated in Harmon (2013), agree, however, that the conflict over construction conflicts is particularly unacceptable and must, therefore, be assumed to be the last resort.

\section{METHODOLOGY}

Practice of questionnaire assessment were carried out to realize the aim of this study and previous works was also reviewed. Study inquiries are as follows: What are the fundamentals that have an effect against the use of arbitration? What are the disputants' opinions of arbitration as in contradiction of lawsuit in terms of cost, time, and maintenance and sustainability of relationship? The research queries and the survey were refined through a pilot study that includes two committed professionals in the area of construction regulation and project management and two other academics with extensive knowledge in the subject area.

Based on the feedback received in the pilot survey the questions were modified. A complete-scale review was then conducted following the pilot test exercise.

Data for this study were collected from two main sources which are secondary and primary sources.

Secondary data were collected from associated literature on former studies while primary data were gathered from the investigation. The questions were separated into 3 segments: section 1 consists of the general information about the respondents. 
Section 2 of the questionnaire was to stimulate responses from the respondents on the issues that militate against the use of arbitration. Section 3 of the questionnaire was to collect data from the respondent on how arbitration give gratification to disputants in solving communal construction disputes in Nigeria. This was designed to be measured in terms of the cost, time, and the sustainability and maintenance of associations between the parties after. For this study, the office of the Federal Ministry of Works, the state ministry of works, and ten local government offices were recognized within Owerri Municipal Council Area in Imo State, Nigeria. Four organizations of higher learning were also identified. A list of contractors was gotten from the federation of building and civil engineering contractors of Nigeria, Imo State branch.

\section{A Results and Discussion}

100 questionnaires were issued, as shown in Table 3.1, to p ublic and creative building practitioners. 68 responses were reverted while only 57 questionnaires were correctly completed and found useful for the study. The answer rate $57 \%$.

Table- III: Response to Questionnaire

\begin{tabular}{|l|l|l|}
\hline & Number & Percentage (\%) \\
\hline Total number returned & $\mathbf{6 8}$ & $\mathbf{6 8} \%$ \\
\hline $\begin{array}{l}\text { Total } \\
\text { number not } \\
\text { returned }\end{array}$ & 32 & $\mathbf{3 2} \%$ \\
\hline $\begin{array}{l}\text { Total number of the } \\
\text { questionnaire distributed }\end{array}$ & $\mathbf{1 0 0}$ & $\mathbf{1 0 0} \%$ \\
\hline
\end{tabular}

Above indicates that the lack of knowledge of the nature of arbitration at the informal sector placed highest, with with government rule on the implementation of arbitration $r$ anking bottommost among those facts or which oppose the arbitration in Nigeria.

Table- III: Factors that affect the use of arbitration in the informal sector of the construction industry.

arbitration existence

Scarcity of knowledge in the use

of arbitration

Absence of teaching and

education on arbitration

Absence of a satisfactory

institutional structure

Impediment by related laws and

regulations

Government rule on the use of

arbitration approaches

\begin{tabular}{|l|l|}
\hline 4.00 & 1 \\
\hline 3.58 & 2 \\
\hline 3.53 & 3 \\
\hline 3.37 & 4 \\
\hline 3.11 & 5 \\
\hline 3.05 & 6 \\
\hline
\end{tabular}

Table- III: Disputants' satisfaction with the use of Arbitration as against litigation in terms of cost

\begin{tabular}{|l|l|l|}
\hline Dispute Resolution Methods & Mean score & Rank \\
\hline Litigation & 3.70 & 2 \\
\hline Arbitration & 4.56 & 1 \\
\hline
\end{tabular}

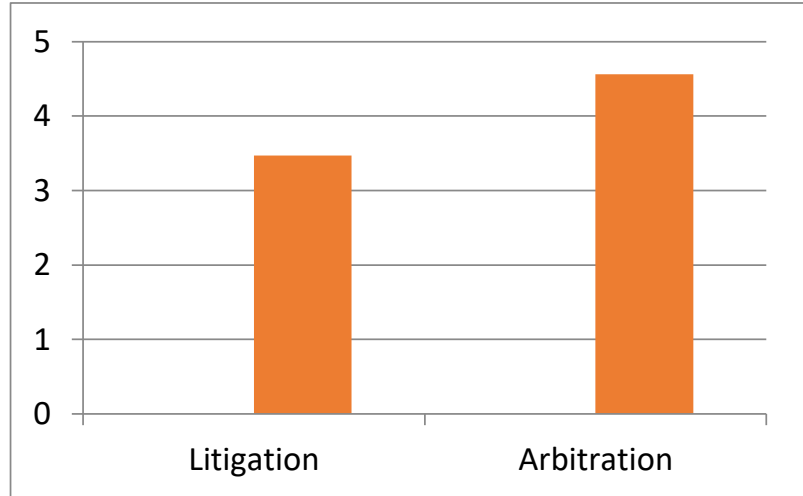

Fig. 1, Explains the table above that arbitration through the highest score of 4.56 ranks peak as the dispute resolution method which springs fulfilment to the disagreement in terms of the money spent on the resolution of disagreements on public construction projects, as in contrast to litigation with a mean score of 3.47 .

Table- III: Disputants' contentment with the use of Arbitration as against lawsuit in terms of the period spent

\begin{tabular}{|ccc} 
Dispute Resolution Methods & Mean Score & Rank \\
\hline Litigation & 2.46 & 2 \\
Arbitration & 4.68 & 1
\end{tabular}

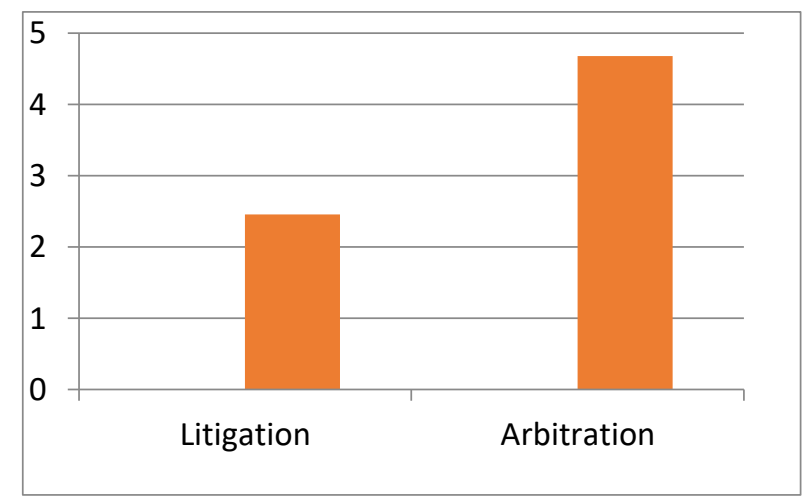

Fig. 2: Explains that table above. Ranks arbitration maximum as the dispute resolution technique as against litigation which provides fulfillment to the disputants in terms of the time taken for the resolution of disagreements on public construction projects.

Table -III: Disputants' fulfillment with the procedure of Arbitration as against lawsuit in terms of maintenance and sustainability of relationships

\begin{tabular}{|l|l|l|}
\hline Dispute Resolution Methods & Mean score & Rank \\
\hline Litigation & 2.02 & 2 \\
\hline Arbitration & 4.51 & 1 \\
$\begin{array}{l}\text { Published By: } \\
\text { Blue Eyes Intelligence Engineering } \\
\text { \& Sciences Publication } \\
\text { (c) Copyright: All rights reserved. }\end{array}$
\end{tabular}




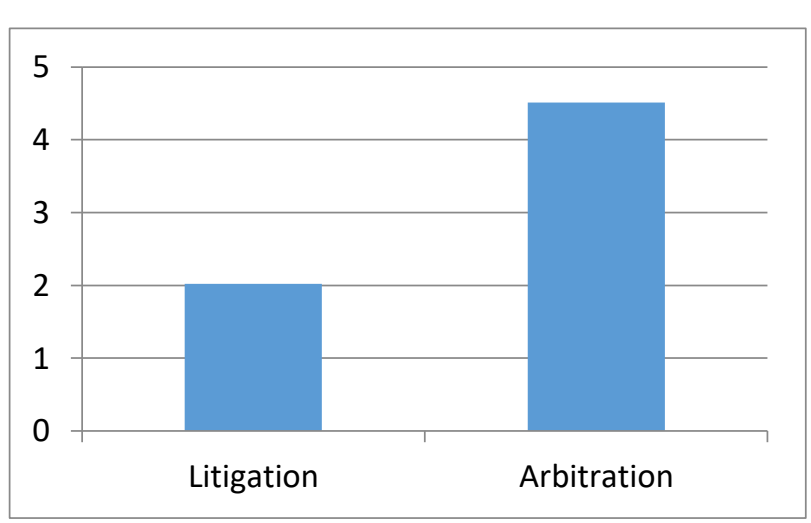

Fig. 3, shows arbitration scoring 4.51 ranks highest as a resolution method to disagreement which gives fulfilment to both parties in terms of preservation and sustainability of relationships as contrary to lawsuit with a score of 2.01.

\section{DISCUSSIONS AND CONCLUSIONS}

\section{A Discussions}

Proceeding the research question, what are the reasons influence the use of arbitration? The study instigates that general lack of consciousness of the existence of arbitration particularly in the informal sector which constitutes a large amount of the construction industry as uppermost factor that influences the use of arbitration in the Nigerian construction industry. Which is followed by the scarcity of skill in the use of negotiation. This finding approves that an overall lack of awareness on the reality of arbitration as the greatest factor that influences the widespread use of arbitration in Nigeria. construction developments can be linked to lack in experience and training. In direction to know how actual arbitration is in resolving public construction disagreements in Nigeria, the regularity at which this method is used as well as how effective they are in bringing about a lasting/ final resolution to the disagreements was assessed. From the analysis, it was found that, in assessing the effectiveness of arbitration over litigation in terms of putting an end to construction disputes, arbitration was found to be the best method that always put an end to construction disputes on public projects.

\section{B Conclusions}

In many countries of the world, arbitration has been used as an alternate for dispute resolution (ADR), which is a form of dispute settlement outside a courtroom. Disagreements and misunderstanding in construction ventures have been seen as unlikable events in the application of projects by numerous researchers and both partake a negative effect on costs, performance, and complete objectives. Such conflicts when settled by litigation and lawsuits, the commercial ties are ultimately destroyed. Arbitration has remained found to be money operational and also not as much time overwhelming. Also, the use of arbitration is further simplified by the inclusion of an arbitration clause in most construction contracts which usually states that all disputes arising in the contract will be settled by arbitration. Use of arbitration in resolving disagreements arising from construction contracts do not only minimizes cost and time but also facilitates cordial relationships among the parties after the dispute and this minimizes the incidence of project failure and This study also agreed that the use of arbitration for

abandonment in the construction business. Disagreements must be resolved properly and professionally, so that good connections between the parties can be preserved since a developing company thrives on partnerships that were founded on past projects and previous interactions.

\section{REFERENCES}

1. Acharya, N and Lee, Y (2006). Conflicting factors in construction projects: Korean perspective. Engineering, Construction, and Architectural Management13(6):543-566.

2. Al-Tabtabai, H., and Thomas, V. (2004). Negotiation and resolution of conflict using AHP: an application to project management. Engineering, Construction, and Architectural Management, 11(2):90-100.

3. Blake, D.W (2006). Scope for improvement: a survey of pressure points in Australian construction and infrastructure projects, Australian Constructors Association

4. Chan, E.H.W, and Suen, H. (2005), Dispute resolution management for international construction projects in China. Management Decision, 43 (4):589-602.

5. Cheung and Suen (2012). A multi-attribute utility model for dispute resolution strategy selection. Construction Management and Economics, 20(7),557-568

6. Cheung, S. (1999). Critical factors affecting the use of alternative dispute resolution processes in construction, International Journal of Project Management,17, (3):189-194.

7. Cheung, S.O, and Yiu, T.W (2006). Are Construction disputes inevitable?, IEEE Transaction Engineering Management,53(3):456-470.

8. Cheung, S. O.; Yiu, T. W.; and Chan, H. W. (2010) Exploring the Potential for Predicting Project Dispute Resolution Satisfaction Using LogisticRegression.508-517

9. Dubois, A., and Gadde, L.(2002). The construction industry as a loosely coupled system: implications for productivity and innovation. Construction Management and Economics, 20 (1):621-631.

10. El-adaway, I. H., and Ezeldin, S. (2007). Dispute review boards: Expected application on Egyptian large scale construction projects. J.Profl. Issues Eng. Educ. Pract., 133(4):365-372

11. Fenn, P (2007). Predicting construction disputes: an aetiological approach. Management Procurement and Law, 160(2):69-73

12. Fenn, P., O'Shea, M., and Davies, E. (Eds) (1998). Dispute resolution and management in construction: An international review, E\&FNSpon,

13. Harmon, K. L. J. (2013) Resolution of construction disputes: A review of current methodologies. Leadership and Management in Engineering, 2(1):187-201

14. Kassab, M., Hipel, K., and Hegazy, T. (2006). Conflict resolution in construction disputes using the graph model. ASCE Journal of Construction Engineering and Management, 132(10), 1043-52.

15. Kululanga, G. K., Koutcha, W., McCaffer, R., and Edum-Fotwe, F.(2011). Construction contractors claim process framework." $J$. Constr. Eng. Manage. 127(4):309-314.

16. Kumaraswamy, M.H. (1997). Conflicts, claims, and disputes in construction. Engineering, Construction, and Architectural Management, 4(2):66-74.

17. Love, P. Davis, P. Ellis, J. \& Cheung, S. O.(2010) Dispute causation of pathogenic influences in construction. Engineering Construction and Architectural Management, 17 (4):404-423.

18. Love, P. Davis, P. London, K. and Jasper, T. (2008). Causal Modeling of Construction Disputes, in Dainty, A.R.J. (ed), Proceedings of the 24th Annual Conference ofARCOM (Association of Researchers in Construction Management), Cardiff, Sep 2008, pp. 869- 878. Reading, UK: ARCOM available athttp://hdl.handle.net/1959.13/45034.

19. Mitropoulos, P., and Howell, G. (2001). Model for understanding preventing and resolving project disputes, ASCE Journal of Construction, Engineering and Management, 127(3):223-31

20. Na Ayudhya, B. I. (2011). Common disputes related to public work projects in Thailand. Songklanakarin J. Sci. Technol. 33 (5):565-573.

21. Ndekugri, I. and Russell, V. (2006) Disputing the existence of a dispute as a strategy for avoiding construction adjudication. Engineering, Construction, and Architectural Management, 13 ( 4):380-395.

\section{Published By:}

Blue Eyes Intelligence Engineering

\& Sciences Publication

(C) Copyriaht: All rights reserved.

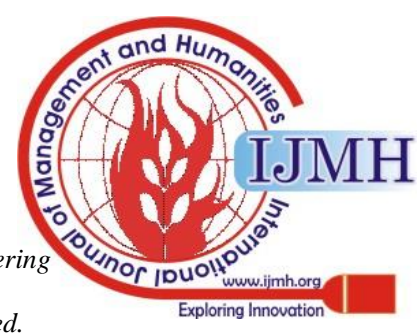


22. Oladapo, A. and Onabanjo, B. (2009) 'A study of the causes and resolution of disputes in the Nigerian Construction Industry'

23. Otoo, J. (2010). The Use of Animation in the Resolution of Construction Dispute. Proceedings of CIBW113

24. Reid, A., and Ellis, R. C. T. (2007). Common sense applied to the definition of a dispute. Structural Survey Vol. 25 No. 3/4, 2007 pp. 239-252 available at www.emeraldinsight.com/0263-080X.htm

25. Sayed-Gharib, T. Price, A. and Lord, W. (2010). Improving Dispute Resolution on Construction Projects in Kuwait. "Proceedings of CIB W113- Special Track Worldbuilding congress", Salford, United Kingdom.10-13 May,p520

26. Taylor, J.M, and Carn W.C (2010) Dispute Resolution in U.S. Commercial Construction: A Practical Approach. Proceedings of CIB W113- Special Track Worldbuilding congress, Salford, United Kingdom.10-13 May;25-34

27. Tazelaar, F.; Snijders, C. (2010) Dispute resolution and litigation in the construction industry. Evidence on conflicts and conflict resolution in the Netherlands and Germany. Journal of Purchasing and Supply Management, 16(4):221-229

28. Zack, J. G. (1995). Practical dispute management. Cost Eng., 37 (12)55.

29. Zaneldin, E. K.(2006). Construction claims in the United Arab Emirates: Types, causes, and frequency. International Journal of Project Management, 24:453-459. available online at www.sciencedirect.com

30. Zuhairah, A.A.G., Azlinor, S., and Rozina, M.Z. (2010). Alternative Dispute Resolution in the Malaysian Construction Industry. Proceedings of CIB W113- Special Track Worldbuilding congress, Salford, United Kingdom.10-13 May atp.53.

\section{AUTHORS PROFILE}

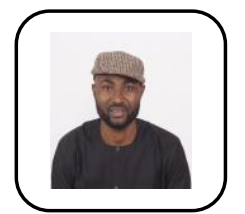

Henry Chidiebere Ajaelu, Ph.D. in Environmental Management and Control, M.Sc Facility Management, B.Sc Quantity Surveying, and also Ph.D. Quantity Surveying (in View). He works as an Academic Technologist in the Department of Urban and Regional Planning, Enugu University of Science and Technology (ESUT), Nigeria, a member of the Nigerian Meteorological Society and Nigerian Institute of Quantity Surveying.

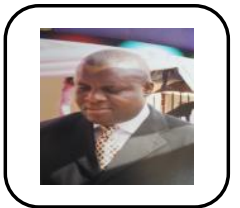

Reuben A. Okereke, PhD QS \& Sust. Dev., MSc. Const. Mgt., MSc. Env. Res. Mgt., FRQS, FIIA, FAPM, ACArb, CIPM, MAACEI., is a multi-talented and erudite scholar. A versatile professional with academic qualifications in Quantity Surveying, Project Management, Construction Management and Environmental Resource Management. His Quantity Surveying professional experience of almost three decades spans through his employment with consultancy and construction firms in Lagos, Nigeria, work as Project Manager in the Bank for eight years, services as in-house consultant Quantity Surveyor for several years for the Imo State University Owerri, Nigeria, experience as Consultant Quantity Surveyor in private practice as well as several years of teaching in both the University and Polytechnic.He is currently serving his second term as the head of department of Quantity Surveying, Imo State University, Owerri, Nigeria. 